\title{
Pharmacological approach for the management of patient with carpal tunnel syndrome associated to diabetic polyneuropathy. Case report
}

\author{
Conduta farmacológica no tratamento de paciente com síndrome do túnel do carpo associada \\ à polineuropatia diabética. Relato do caso
}

Marcelo Antônio Oliveira Santos ${ }^{1}$, Lucas Soares Bezerra1, Francisco Nêuton de Oliveira Magalhães²

\section{ABSTRACT}

BACKGROUND AND OBJECTIVES: Peripheral neuropathy and carpal tunnel syndrome are debilitating diseases associated to diabetes mellitus in 12 to $21 \%$ of cases. There are no significant evidences of the clinical differentiation between such painful syndromes and their specific management. This study aimed at reporting the clinical presentation of a patient with peripheral polyneuropathy associated to carpal tunnel syndrome, focusing on therapeuthic approaches and discussing clinical differentiation between both diseases.

CASE REPORT: Male patient, 68 years old, married, retired, who looked for medical assistance complaining of burning pain, especially in left upper limb. He also referred pain in lower limbs with night exacerbation, in addition to numbness in extremities and pain intensity of 6 in the visual analog scale. Presence of trigger-points in trapezius and levator scapulae muscles. Patient was submitted to decompression surgery due to carpal tunnel syndrome diagnosis two years ago, however without postoperative improvement. Patient refers pain in upper and lower limbs, with nocturnal exacerbation, numbness and pain in extremities. He has history of hypertension, diabetes mellitus type 2 and leprosy. At physical evaluation: painful boot and glove hypoesthesia and possible motor deficit in C6 and C7. Electromyography showed mixed peripheral polyneuropathy of lower limbs and median carpal syndrome to the left. There has been movement amplitude improvement in myotomes C6 and C7. Pain decreased to 3 in the visual analog scale after two weeks under gabapentin and duloxetine.

CONCLUSION: It is difficult to clinically differentiate between neuropathy of different etiology and peripheral polyneuropathy. The proposed treatment has provided $50 \%$ improvement in the

1. Centro Universitário Maurício de Nassau, Recife, PE, Brasil.

2. Universidade de Sáo Paulo, São Paulo, SP, Brasil.

Submitted in June 17, 2015.

Accepted for publication in October 20, 2015.

Conflict of interests: none - Sponsoring sources: none.

Correspondence to:

Marcelo Antônio Oliveira Santos

Rua Sideral, 285 - Boa Viagem

51030-630 Recife, PE, Brasil.

E-mail: marcelosantos.med@gmail.com

(C) Sociedade Brasileira para o Estudo da Dor visual analog scale two weeks later. Lidocaine infusion at 5\% has provided acute improvement of patient's pain.

Keywords: Carpal tunnel syndrome, Diabetic Neuropathy, Pharmacotherapy.

\section{RESUMO}

JUSTIFICATIVA E OBJETIVOS: Polineuropatia periférica e síndrome do túnel do carpo são doenças debilitantes, associadas ao diabetes mellitus em cerca de 12 a $21 \%$ dos casos. Inexistem evidências significativas que direcionem sobre a diferenciação clinica entre essas síndromes dolorosas e o tratamento específico. $\mathrm{O}$ objetivo deste estudo foi relatar o quadro clínico de um paciente que apresentou polineuropatia periférica associada à síndrome do túnel do carpo, enfocando nas medidas terapêuticas e discutindo acerca da diferenciação clínica entre as doenças referidas. RELATO DO CASO: Paciente do gênero masculino, 68 anos, casado, aposentado buscou atendimento médico por queixa de dor queimante, sobretudo em membro superior esquerdo. Refere dor também em membros inferiores, com exacerbação noturna, além de dormência nas extremidades, intensidade de 6 na escala visual analógica. Presença de ponto-gatilho nos músculos trapézio e elevador da escápula. Passou por cirurgia de liberação por diagnóstico de síndrome túnel do carpo há 2 anos, sem melhora pós-cirúrgica. Tem histórico de hipertensão arterial, diabetes mellitus tipo 2 e hanseníase. No exame físico: presença de hipoestesia dolorosa em bota e luva e possível déficit motor em C6 e C7. Eletromiografia evidencia polineuropatia periférica mista de membros inferiores e síndrome do túnel do carpo mediana à esquerda. Houve melhora na amplitude de movimento nos miótomos C6 e C7. A dor foi para 3 na escala visual analógica após 2 semanas sob uso de gabapentina e duloxetina.

CONCLUSÃO: É difícil a diferenciação clínica entre neuropatia de outra etiologia e polineuropatia periférica. $\mathrm{O}$ tratamento proposto trouxe uma melhora na escala analógica visual de $50 \%$ após duas semanas. A infusão de lidocaína a 5\% representou melhora aguda na dor referida pelo paciente.

Descritores: Farmacoterapia, Neuropatia diabética, Síndrome do túnel do carpo.

\section{INTRODUCTION}

Peripheral polyneuropathy (PPN) is a condition affecting more than one peripheral nerve, which induces sensitive and/ or motor changes, being a complication secondary to diabe- 
tes mellitus (DM) in approximately 12 to $21 \%$ of patients, being in this case called diabetic polyneuropathy (DPN $)^{1,2}$. Symptoms are in general symmetrically distributed in "boot or glove" pattern, with exacerbation at night. Carpal tunnel syndrome (CTS) is the most common affection among those related to peripheral nerves compression and DM is knowingly a risk factor for CTS, which affects approximately $45 \%$ of diabetic patients as compared to $12 \%$ of general population ${ }^{3,4}$. Clinical association between median neuropathy at the wrist, the electromyographic study of which in general reveals CTS, and DPN is present in about $29 \%$ of patients in whom it is presented as early manifestation of diabetic polyneuropathys.

The literature satisfactorily addresses indications and recommendations for pharmacological treatment of neuropathic pain. For this purpose tricyclic antidepressants, selective inhibitors of $5 \mathrm{HT}$ and norepinephrine reuptake, gabapentin, pregabalin and topic lidocaine infiltration may be used ${ }^{6}$. However, there are not significant evidences directing a specific pharmacological management to patients in whom DPN and CTS are associated.

So, this study aimed at reporting a case of a patient with DPN associated to CTS, focusing on clinical differentiation, and at discussing most effective therapeutic measures in the pharmacological field.

\section{CASE REPORT}

Male patient, 68 years old, married, retired three years ago and who worked as industrial cook, with major complaint of left hand pain starting six years ago. Pain was diffuse, burning, being constant along the day (especially in left upper limb) and associated to night exacerbation and numbness in extremities. Intensity was classified by the visual analog scale (VAS) as $6 / 10$ for lower limbs (LLLL) and upper limbs (UULL).

Patient was submitted to surgery due to CTS diagnosis two years ago, however without postoperative improvement. Patient has history of leprosy for eight years, is hypertensive and has DM type II. Patient was under previous use of losartan, metformin and gabapentin, being the latter discontinued by him due to no pain improvement.

At physical evaluation patient was conscious and oriented with painful hypoesthesia in boot and glove, signs of motor deficit in $\mathrm{C} 6$ and $\mathrm{C} 7$ and presence of trigger-points in trapezius and levator scapulae muscles. Electromyography has shown mixed peripheral polyneuropathy of LLLL and marked CTS to the left. We have also asked for magnetic resonance (MR) of cervical spine which has not shown significant changes.

Initial pharmacological approach to treat baseline diseases was to maintain losartan and metformin. For the former, a dose of $50 \mathrm{mg} /$ day was prescribed. For the latter, initial dose, which was one $850 \mathrm{mg} /$ day tablet, was adjusted to two 500 $\mathrm{mg} /$ day tablets. Losartan was maintained to treat hypertension. Metformin, a biguanide which increases sensitivity to insulin, is justified to control DM, factor which triggers peripheral nerves changes culminating with DPN.
Although gabapentin is the most widely indicated first line to treat neuropathic syndromes, patient has reported that its previous use for six months had not improved pain. So, we decided to reintroduce gabapentin in the dose of $30 \mathrm{mg} /$ day associated to $30 \mathrm{mg} /$ day of duloxetine.

Pain, induced both by DPN and CTS, was managed with the association of gabapentin (which was reintroduced in the dose of $300 \mathrm{mg} /$ day) and duloxetine $(30 \mathrm{mg} /$ day $)$.

In addition to prescribed drugs, we also decided for a local injection of 5\% lidocaine in painful areas, performed at consultation time.

Two weeks later, and adhering to proposed treatment, patient returned and reported major improvement and further amplitude of movements which before could not be performed due to recurrent pain. Pain intensity in LLLL and UULL, which initially was approximately $6 / 10$ has improved to $3 / 10$ according to VAS.

\section{DISCUSSION}

Painful, hypoesthetic and paresthetic symptoms of CTS are induced by medial nerve compression which may be caused by issues such as tenosynovial proliferation, tumor, wrist joint abnormality or muscle anomaly ${ }^{7}$, as well as any other situation increasing pressure of decreasing volume of the carpal tunnel. Major risk factors for this disease include pregnancy, hypothyroidism DM, obesity, renal failure, wrist fracture and occupation. With regard to the latter, it is known that CTS affects approximately $1 \%$ of retired workers and is the major reason of pain in hands of those performing manual work ${ }^{8}$. Diabetic polyneuropathy is a complication of diabetes (1 and 2), being characterized by progressive distal axonal degeneration, in addition to demyelination and axonal loss'. The pathway leading to painful symptoms is the injury of sensory and motor fibers, or both, caused by high glycemia levels, which may occur in local fibers in case of mononeuropathy, or in several fibers in case of polyneuropathy. Most common symptoms are painful paresthesia and sensory ataxia, which may affect up to $50 \%$ of DM type 2 patients. From the general picture, approximately $90 \%$ are represented by Diabetic Painful Distal Symmetrical (DSPN), disease which is often associated to CTS ${ }^{10,11}$.

A major point of clinical differentiation between both diseases is that in CTS patients in general precisely describe the distribution of sensory disorders from the palm to finger tips (frequently middle finger), predominantly in the dominating hand ( $80 \%$ of cases), irradiating to shoulder. In DPN, symptoms have a uniform bilateral distribution, both in LLLL and UULL extremities in a distribution pattern known as boot and glove. While CTS symptoms are frequently associated to repetitive mechanical effort patterns, DPN symptoms are more related to exacerbation at night ${ }^{1,2,7-9}$.

In our patient, the history of leprosy could be a risk factor, in addition to DM and occupation, leading to further morbidity of neuropathic painful syndromes, which could be explained by the trend of such patients to develop thin fibers neuropathy. In addition, Von Gierke et al. ${ }^{12}$ have reported a 
curious case of CTS as leprosy complication, which seems to have been caused by a possible latency of decades of the leprous neuritis ${ }^{12}$. However, there are no further evidences in the literature to confirm such relationship.

In addition to history and physical evaluation, electroneuromyography is the standard method for diagnostic confirmation of peripheral neuropathies. However, it is not uncommon to find changes in asymptomatic patients, however such changes are an additional risk factor for the development of the disease. With regard to CTS, evidences suggest that positive electromyography in asymptomatic diabetic patients represents increased risk factor for the development of other neuropathies, including DPN. Ultrasound is also a useful tool to help in the differential diagnosis of patients with CTS associated or not to DPN, by measuring the cross-sectional area (CSA) of the medial nerve. CSA cutoff value favoring the association between both diseases varies from $10.5 \mathrm{~mm}^{2}$ to $11.6 \mathrm{~mm}^{2}$, with sensitivity and specificity of up to 73 and $90 \%$, respectively ${ }^{13}$.

Final clinical treatment for CTS is in general decompression surgery. Postsurgical improvement rate for DM patients is around $68 \%$ and it seems to be clinically lower as compared to a non-diabetic control group ${ }^{14}$. Another option is pharmacological therapy to control pain. Among options, a mean dose of $1800 \mathrm{mg} /$ day of gabapentin has resulted in $40 \%$ decrease in symptoms pain intensity and functional level improvement of patients at the end of six months ${ }^{15}$. There are few studies on the efficacy of duloxetine and other drugs to treat CTS.

In case of DPN, treatment consists in controlling the baseline disease (DM) by controlling glycemia aiming at preventing the progression of damage to neuronal fibers, and in controlling pain induced by already established injuries. Analyzing most recent guidelines of the American Academy of Neurology $(\mathrm{AAN})^{16}$, of the European Federation of Neurological Societies (EFNS $)^{17}$ and of the National Institute for Health and Clinical Excellence (NIHCE) ${ }^{18}$, it was observed that both gabapentin and duloxetine are recommended as first or second choice drugs to treat such patients, as shown in table 1 .

In our case, patient was refractory to decompression surgery and to gabapentin, which are first line therapies for CTS and

Table 1. Guidelines to treat painful diabetic neuropathy

\begin{tabular}{lccc}
\hline & EFNS (2010) & AAN (2011) & NIHCE $(2013)$ \\
\hline Pregabalin & $1^{\text {st }}$ & $1^{\text {st }}$ & $1^{\text {st }}$ or $2^{\text {nd }}$ \\
Gabapentin & $1^{\text {st }}$ & $2^{\text {nd }}$ & $1^{\text {st }}$ or $2^{\text {nd }}$ \\
Duloxetine & $1^{\text {st }}$ & $2^{\text {nd }}$ & $1^{\text {st }}$ or $2^{\text {nd }}$ \\
Tricyclic & $1^{\text {st }}$ & $2^{\text {nd }}$ & $1^{\text {st }}$ or $2^{\text {nd }}$ \\
antidepressants & & & \\
Opioids & $2^{\text {nd }}$ or $3^{\text {rd }}$ & $2^{\text {nd }}$ & - \\
$5 \%$ Lidocaine & - & $3^{\text {rd }}$ & - \\
Carbamazepine & $\mathrm{NI}$ & - & -
\end{tabular}

$1^{\text {st }}, 2^{\text {nd }}$ and $3^{\text {rd }}=$ first, second and third choice, respectively. EFNS = European Federation of Neurological Societies; AAN = American Academy of Neurology; $\mathrm{NIHCE}=$ National Institute for Health and Clinical Excellence; $\mathrm{NI}=$ not indicated. - = not mentioned.
DPN, respectively. Since there is no formal indication in the guidelines for the treatment of both associated syndromes, we decided to maintain gabapentin in the dose of $30 \mathrm{mg} /$ day because it is formally indicated to treat DPN and has beneficial results with regard to improving CTS pain, although in a significantly lower dose. Following guidelines recommendations, duloxetine in the dose of $30 \mathrm{mg} /$ day was associated.

Topic 5\% lidocaine infusion is justified due to its efficacy (65\%) for acute neuropathic pain control, effect which is comparable or even better than the use of pregabalin. Pain control duration is approximately 7-8 hours and its efficacy may be maintained to up to one week ${ }^{12,19}$.

\section{CONCLUSION}

It is difficult to clinically differentiate between neuropathy of a different etiology and PPN. However, with specific diagnosis and treatment patient had a positive response.

\section{REFERENCES}

1. Aslam A, Singh J, Rajbhandari S. Pathogenesis of painful diabetic neuropathy. Pain Res Treat. 2014;412041

2. Said G. Diabetic neuropathy--a review. Nat Clin Pract Neurol. 2007;3(6):331-40.

3. Jeong $\mathrm{DH}, \mathrm{Kim} \mathrm{CH}$. The Quantitative relationship between physical examinations and the nerve conduction of the carpal tunnel syndrome in patients with and without a diabetic polyneuropathy. Ann Rehabil Med. 2014;38(1):57-63.

4. Jenkins PJ, Duckworth AD, Watts AC, McEachan JE. The outcome of carpal tunnel decompression in patients with diabetes mellitus. J Bone Joint Surg Br. 2012;94(6):811-4.

5. Horinouchi S, Deguchi T, Arimura K, Arimura A, Dochi Y, Uto T, et al. Median neuropathy at the wrist as an early manifestation of diabetic neuropathy. J Diabetes Investig. 2014;5(6):709-13.

6. Dworkin RH, O'Connor AB, Audette J, Baron R, Gourlay GK, Haanpää ML, et al. Recommendations for the pharmacological management of neuropathic pain: an overview and literature update. Mayo Clin Proc. 2010;85(3 Suppl):S3-14.

7. Marciano LH, Leite VM, Araújo, PM, Garbino JA. Avaliação do comprometimento neurológico e da prevalência da síndrome do túnel do carpo em pacientes portadores de diabetes mellitus tipo 2. Acta Fisiátrica. 2007;14(3):134-41.

8. Saint-Lary O, Rébois A, Mediouni Z, Descatha A. Carpal tunnel syndrome: primary care and occupational factor. Front Med. 2015;2:28.

9. Mizukami H, Yagihashi S. Exploring a new therapy for diabetic polyneuropathy - the application of stem cell transplantation. Front Endocrinol (Lausanne). 2014;5:45.

10. Tesfaye S, Boulton AJ, Dickenson AH. Mechanisms and management of diabetic painful distal symmetrical polyneuropathy. Diabetes Care. 2013;36(9):2456-65.

11. Gangliardi AR. Neuropatia diabética periférica. J Vasc Br. 2003;2(1):67-74.

12. von Gierke U, Stagelschmidt P, Prantl F, Strian F, Flaschenträger T. [A rare cause of carpal tunnel syndrome: leprosy. Latency period of decades is possible. MMW Fortschr Med. 2000;142(10):39-40. German.

13. Kim WK, Kwon SH, Lee SH, Sunwoo IN. Asymptomatic electrophysiologic carpal tunnel syndrome in diabetics: entrapment or polyneuropathy. Yonsei Med J. 2000;41(1):123-7.

14. Ozer K, Malay S, Toker S, Chung KC. Minimal clinically important difference of carpal tunnel release in diabetic and nondiabetic patients. Plast Reconstr Surg. 2013;131(6):1279-85.

15. Erdemoglu A K. The efficacy and safety of gabapentin in carpal tunnel patients: Open label trial. Neurol India 2009;57(1):300-3.

16. Bril V, England J, Franklin GM, Backonja M, Cohen J, Del Toro D, et al. Evidence-based guideline: treatment of painful diabetic neuropathy: report of the American Academy of Neurology, the American Association of Neuromuscular and Electrodiagnostic Medicine, and the American Academy of Physical Medicine and Rehabilitation. Neurology. 2011;76(20):1758-65.

17. Attal N, Cruccu G, Baron R, Haanpää M, Hansson P, Jensen TS, et al. EFNS guidelines on the pharmacological treatment of neuropathic pain: 2010 revision. European Federation of Neurological Societies. Eur J Neurol. 2010;17(9):1113-e88.

18. National Institute for Health and Clinical Excellence. Neuropathic pain: the pharmacological management of neuropathic pain in adults in nonspecialist settings. 2010 (Clinical guideline 96)

19. Argoff CE. Topical analgesics in the management of acute and chronic pain. Mayo Clinic Proceedings. 2013;88(2):195-205. 